\title{
Contract archaeology in South Africa: some ethical concerns
}

\author{
Ndukuyakhe Ndlovu* \\ Department of Anthropology and Archaeology, University of Pretoria, Pretoria, Hatfield, 0083, \\ South Africa
}

While contract archaeology has played a significant role in South Africa, a number of ethical concerns have become evident over the years. How enabling are the legal frameworks to contract archaeologists? Whose interest are contract archaeologists serving? How well do they consult affected parties in their work? How well do they communicate their findings, with their colleagues and the public at large? What, if any, has been the role of contract archaeologists in the transformation of South African archaeology? How effective is the current accreditation system run by the Association of Southern African Professional Archaeologists (ASAPA) for contract archaeology in ensuring that specialists operate within fields in which they are experienced? This paper addresses these concerns, focusing on the ethical elements relating to contract archaeology. The aim is to illustrate that while current legislation may have gone some way toward promoting the inclusion of previously excluded communities in the management of heritage resources membership of professional bodies by contract archaeologists still does not best enhance this. ASAPA's failure to ensure that all its members abide by its code of conduct is a cause for concern and it should take steps to improve this situation.

Keywords: contract archaeology; ethics; legal frameworks; accreditation; ASAPA

Si l'archéologie commerciale a joué un rôle important en Afrique du Sud, un nombre de préoccupations éthiques se sont présentées au fil des ans. Dans quelle mesure la législation offre-t-elle un appui aux archéologues commerciaux? De quels groupes les archéologues commerciaux servent-ils les intérêts? Dans quelle mesure consultent-ils les parties affectées dans leur travail? Est-ce qu'ils communiquent de manière adéquate leurs résultats aux collègues et au public? Quel a été le rôle des archéologues commerciaux dans la transformation de l'archéologie sud-africaine? Le système actuel d'accréditation pour l'archéologie commerciale, mené par l'Association of Southern African Professional Archaeologists (ASAPA) dans le but de garantir que les spécialistes opèrent dans les domaines où ils ont réellement de l'expertise, est-il efficace? Cet article examine ces préoccupations, se focalisant sur les questions éthiques relatives à l'archéologie commerciale. Le but ici est de démontrer que la législation actuelle a effectivement contribué à promouvoir l'inclusion de communautés autrefois exclues de la gestion du patrimoine, mais que l'adhésion des archéologues commerciaux à des organes professionnels est moins efficace sur ce point. L'ASAPA n'a pas su garantir que tous ses membres respectent son code déontologique, ce qui est une source d'inquiétude, et cette association se doit de prendre des mesures pour améliorer cet état de choses.

*Email: ndukuyakhe@googlemail.com 


\section{Introduction}

The archaeological landscape in South Africa has changed significantly in the last three decades. Compared to the past when collectors, archaeological enthusiasts and research archaeologists dominated archaeology, today it is contract archaeologists who are collecting the greatest quantity of archaeological artefacts and related data for museum storage. Rather than explain the past, contract archaeology 'discovers' it, after which, in most cases, it is 'destroyed'. Through this reactive measure, significant archaeological and historic sites are prevented from being damaged under the developer pays approach. This may provide the very last opportunity to locate, record and perhaps even protect sites or parts of them in situ, although some are still destroyed even when identified ahead of development (Figure 1).

Contract archaeology is also known by a number of other names in different parts of the world: developer-funded, cultural resources management, compliance, salvage, rescue and commercial archaeology. I refer to this development-funded practice of archaeology as contract archaeology. According to Kinahan (2013: 1), "there is no doubt that contract archaeologists contribute significantly to knowledge of the archaeological record". Contract archaeology has been effectively used in many other countries (McGimsey 1972; Green and Doershuk 1998; Carter 2002; van Waarden n.d.). In South Africa, elements of contract archaeology date back to the 1970s. The KwaZulu-Natal Museum was one of the first institutions to have a contract archaeologist to assist with dam constructions in the then province of Natal.

However, while contract archaeology in South Africa dates back to the late 1970s, it was only in the late 1980s that it began to flourish, something reflected in the discussions

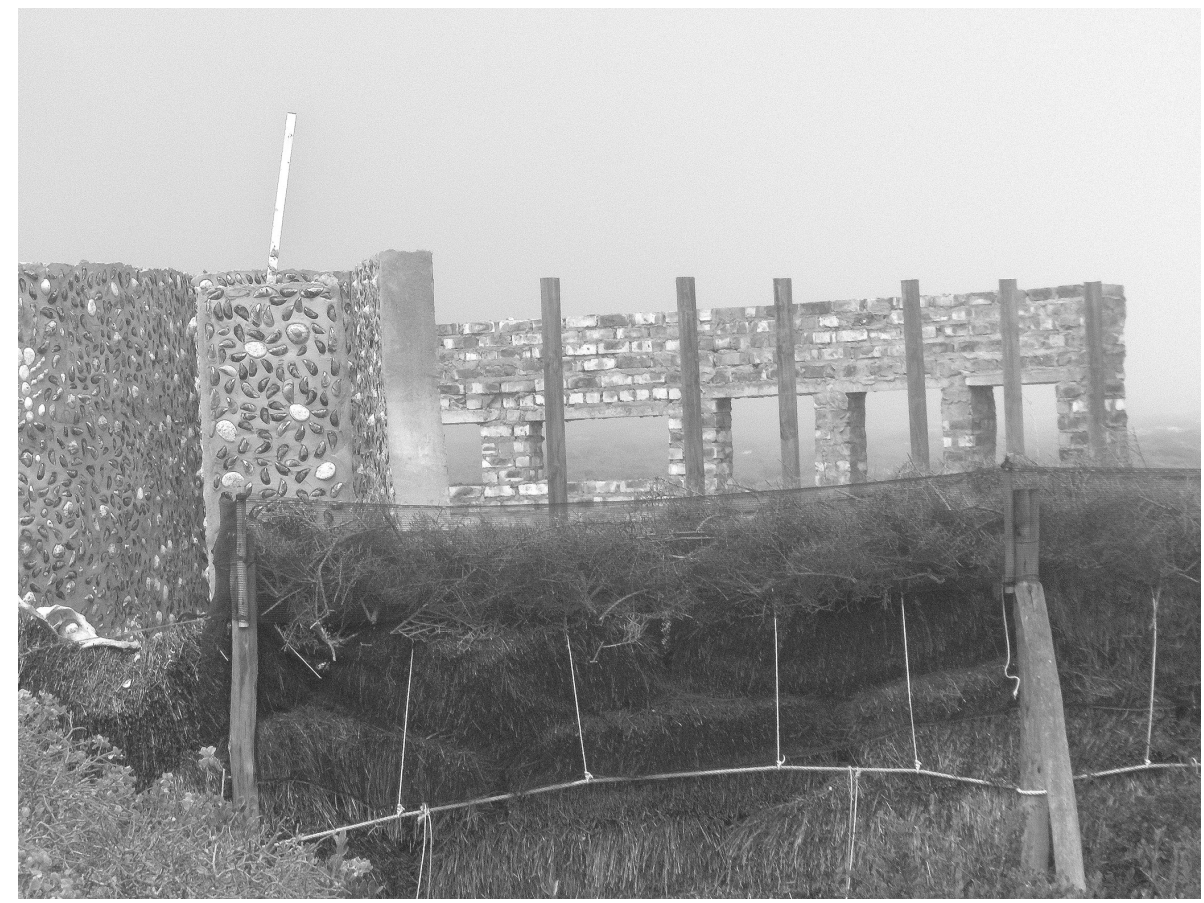

Figure 1. A new building along the West Coast of South Africa (Western Cape Province) where a number of significant shell middens were destroyed (photograph: Ndukuyakhe Ndlovu). 
held by archaeologists at that time over what the future of this sub-discipline should be (H. Deacon 1988; J. Deacon 1993; Hall 1989; Maggs, pers. comm., 2012). The fact that two universities established contracts divisions around this same period is testament to this. The first to do so was the University of Cape Town, which established the Archaeology Contracts Office (ACO) in 1987 under the leadership of David Halkett and Tim Hart, two years before the enactment of the Environmental Conservation Act (No. 73 of 1989). Three years later, in 1990, Archaeological Resources Management was established at the University of the Witwatersrand. These two contract divisions are still in existence today and have deeply entrenched their position in the archaeological landscape by adapting to the new legal requirements of the National Heritage Resources Act (NHRA, No. 25 of 1999). The motivating factor for these universities to establish contract divisions was the recognition that they were able to make much more money through this new service compared to the research arms of their respective archaeology departments (H. Deacon 1988; Hall 1989). Buoyed by this, Hilary Deacon (1988) hailed the advent of contract archaeology as the future of archaeology in South Africa, a prophecy that can, in retrospect, certainly not be considered unfounded as today it is the greatest employer of archaeologists in the country (Kinahan 2013); more and more archaeologists are finding full-time employment in this area rather than academia because job turnover at university departments is very slow (Kinahan 2013).

Assessing this new trend in contract archaeology, Martin Hall (1989) nevertheless warned that, notwithstanding the evident financial benefits, control over the accreditation of contract archaeologists and archaeological practice in this sector of the profession would require attention. Encouraged by a visit to South Africa by a practising North American archaeologist, Dave Frederickson, he specifically argued that a strong professional body would be needed to achieve this and advocated that South Africa learn from the experience of contract archaeology in the United States. As I shall illustrate later, however, accreditation measures appear to have little value in contemporary South African contract archaeology.

Control over accreditation meant establishing the qualifications that a person needed to be considered a professional archaeologist with the ability to practise contract archaeology. Hall's advice was to create a new body for this purpose, rather than expecting either the South African Archaeological Society (with its partly avocational membership) or the Southern African Association of Archaeologists (SA3) to fulfil this task. Specifically, he argued that both these bodies 'have to serve wider, and sometimes contrary, interests than Contract Archaeology' (Hall 1989: 63-64). This advice was not taken. Today it is SA3's successor, the Association for Southern African Professional Archaeologists (ASAPA), that is the mother body of the archaeological discipline in southern Africa as a whole, i.e. not only in South Africa (www.asapa.org.za). With archaeology now recognised as an important component of our heritage across the region, and with that heritage increasingly threatened by urban development, mining (Ndlovu 2012), wind farms (Halkett 2010a, 2010b), dams (van Schalkwyk 2006; Kleinitz 2013) and other projects, ASAPA accredits contract archaeologists and has professional jurisdiction over the practice of archaeology throughout southern Africa (Figure 2; www.asapa.org.za/index.php/members/index.php).

One could argue that the reasoning behind not distinguishing at the end of the 1980s between one professional body for research archaeologists and another for contract archaeologists was unintentionally aimed at addressing the conflicts that had ensued in the United States. The rapid development of contract archaeology there 'led in turn to a division within the discipline itself - if a person was involved with CRM, then they 


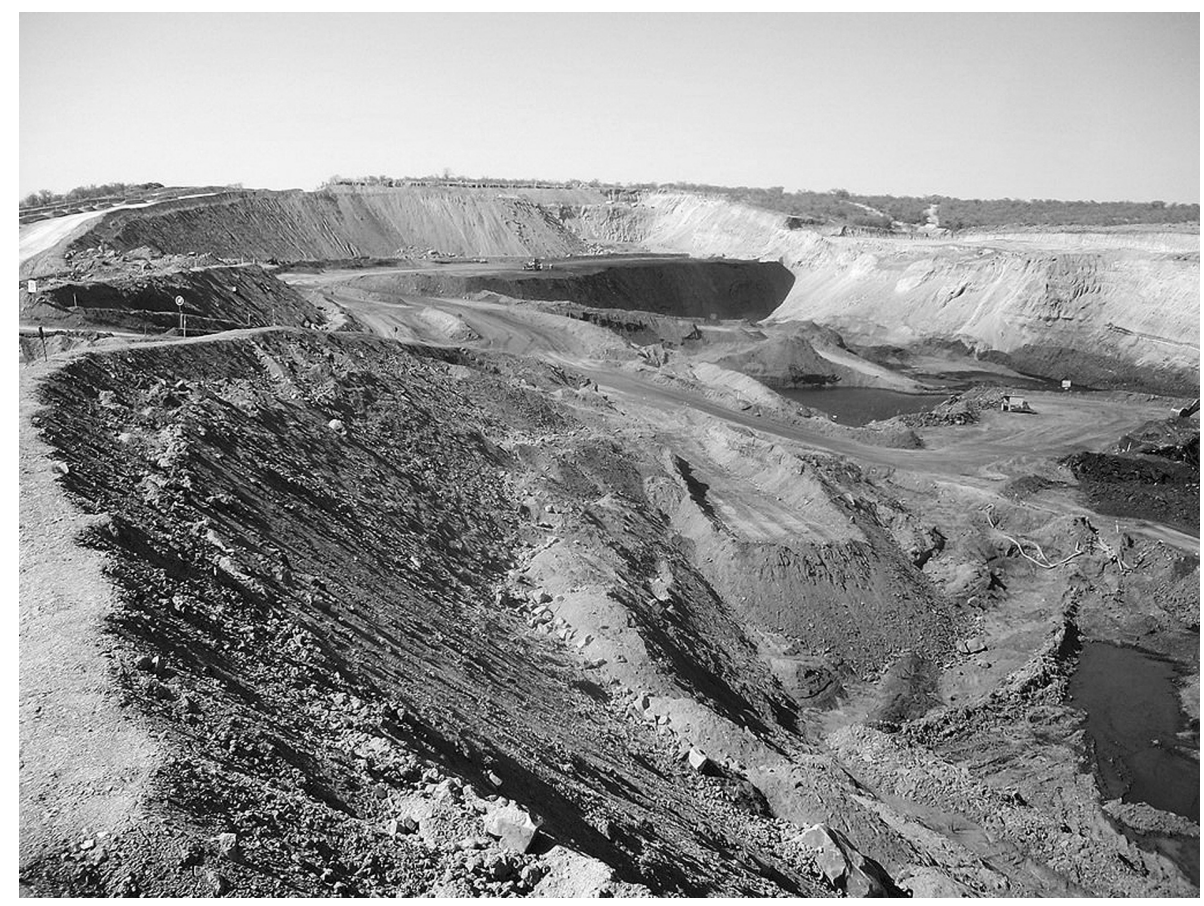

Figure 2. Open cast coal mining near the Mapungubwe Cultural Landscape, Limpopo Province. Before a recent court challenge and other interventions thereafter, a number of archaeological sites were at threat here (photograph: Lisa Chamberlain).

could not be good enough for "pure' research"” (Hall 1989: 63). Ironically, however, even though there is currently a single body in southern Africa for administering both research and contract archaeology, the segregation experienced by archaeologists in the United States is clearly evident, particularly within South Africa. It is within this context of control over accreditation and control of the archaeological practice that I situate my analysis.

Noting the existence of the two contract divisions at the Universities of Cape Town and Witwatersrand, it was the promulgation of the Environmental Conservation Act (No. 73 of 1989) that began to encourage the rise in the application of contract archaeology in South Africa. This legislation empowered the relevant minister to request a report that would assess any potential impacts of a proposed development (J. Deacon 1993). It was not, however, mandatory for contract archaeology to form part of every development requirement and not all developers did so. As a result, the lack of a strong legal mandate meant that contract archaeology did not really take off until the late 1990s when the proclamation into law of the provincial KwaZulu-Natal Heritage Act (No. 10 of 1997) by KwaZulu-Natal, the only province with its own heritage legislation, and, for the rest of South Africa, of the National Heritage Resources Act (NHRA, No. 25 of 1999) gave a breath of fresh air to contract archaeology. Both pieces of legislation replaced the National Monuments Act (No. 28 of 1969) and all its amendments (Rudner 1982). Following this, there has been a significant proliferation of privately owned archaeology consulting firms.

While contract archaeology has played a significant role in South Africa, a number of ethical concerns have become evident over the years. Making reference to the advice of 
Martin Hall regarding putting controls in place, and the advice of Dave Fredrickson not to follow the North American mess, to what extent are the legal frameworks in South Africa promoting ethical considerations by those working in contract archaeology? Whose interests are contract archaeologists serving? How well do they consult affected parties in their work? How well do they communicate their findings, with their colleagues and the public at large? How do they adhere, if at all, to the professional code of conduct as set out in the ASAPA Constitution (www.asapa.org.za/index.php/members/index.php)? I address these concerns focusing on the ethical elements relating to contract archaeology.

\section{Legal frameworks and social consultation in South Africa}

Following the promulgation of the NHRA of 1999, which significantly increased contract archaeology in the country, South Africa began to have a three-tier management system at national, provincial and local locals, reflecting its overall political structure (Scheermeyer 2005; Ndlovu 2011). All previously declared national monuments were downgraded to Provincial Heritage Sites. The South African Heritage Resources Agency (SAHRA), as the national custodian, is responsible for Grade 1 sites, while Provincial Heritage Resources Agencies (PHRAs) have jurisdiction over Grade II sites and local municipalities are supposed to manage Grade III sites. However, the reality is that the majority of municipalities have not taken this responsibility seriously in the same way that some provinces still do not have fully-fledged PHRAs. For example, Cape Town, Johannesburg and eThekwini (Durban and its immediate neighbours) do all have fully fledged heritage units, reflecting their metropolitan status and greater financial power compared to other municipalities. At the provincial level, as a result, Amafa aKwaZulu-Natali (Amafa), Eastern Cape Provincial Heritage Resources Agency (ECPHRA) and Heritage Western Cape (HWC) hold the relevant mandate for the three provinces of KwaZulu-Natal, Eastern Cape and Western Cape. This leaves SAHRA charged with the administration of the NHRA in the remaining six provinces on the basis of the annual agency agreements entered into with the respective Provincial Heritage Councils, although the Northern Cape Province is scheduled to launch its own Provincial Heritage Resources Agency in March 2014.

SAHRA's Council is presently discussing a strategy on how to support the existing Provincial Heritage Resources Agencies, while also establishing the relevant provincial authorities in the remaining provinces of Free State, Gauteng, Limpopo, Mpumalanga and North-West as envisaged by the 1999 National Heritage Resources Act. Existing Provincial Heritage Resources Agencies in these provinces have extremely limited functions pertaining to the built environment, an area in which SAHRA had little historical expertise.

Under the current national heritage legislation, the work of contract archaeology is governed in various ways. First, Section 34 of the 1999 NHRA states that 'no person may alter or demolish any structure or part of a structure which is older than 60 years without a permit issued by the relevant provincial heritage resources authority' This enables the relevant Provincial Heritage Resources Agency to request a historical archaeologist to conduct an assessment into the significance of an old building before a permit may be considered for its demolition. Second, Section 38 of the same Act empowers the heritage agency to request a Heritage Impact Assessment (HIA) if there is reason to believe that heritage resources may be or will be affected by a proposed development. The Archaeological Impact Assessment (AIA) undertaken by contract archaeologists is part of this HIA. There is a tendency to focus mainly on the AIA because of the strength of 
the Archaeology, Palaeontology and Meteorites unit of SAHRA, but the heritage legislation itself refers only to the HIA in an effort to have a holistic approach to heritage management. Third, Sections 35 and 36 of the Act provide for the issuance of permits to destroy and damage archaeological artefacts and to relocate human remains where applicable.

Five pieces of legislation require Heritage Impact Assessments (HIAs) if the proposed development is a listed activity. Heritage Impact Assessments can be part of an Environmental Impact Assessment (EIA) undertaken in terms of the Environmental Conservation Act (No. 73 of 1989, as amended), the National Environment Management Act (as amended, No. 107 of 1998), the Mineral and Petroleum Resources Development Act (No. 28 of 2002), developments specified in Section 38 (1) of the National Heritage Resources Act (No. 25 of 1999) and, finally, the KwaZulu-Natal Heritage Act (No. 4 of 2008). Under both the National Heritage Resources Act (No. 25 of 1999), and the KwaZulu-Natal Heritage Act (No. 4 of 2008), heritage agencies are the deciding authorities. In contrast, they serve merely as commenting authorities for developments undertaken subject to the environmental legislation.

When one considers the impact assessments undertaken under environmental legislation, it is evident that facilitating social consultation with interested and affected parties forms a significant step that the developer, through contracted consultants, must satisfy. Interested and affected parties should be provided with adequate time, as stipulated in law, to provide their comments, which must then be considered in the EIA report. This consultation of the interested and affected parties is generally limited to neighbours (residential and/or commercial) and perhaps those with a particular historical or academic interest. Strictly speaking, there is no legal mandate for Indigenous African communities to be contacted at this stage for their approval or disapproval for the mitigation of heritage sites that may still be ritually significant to them, such as graves. From a purely legal standpoint this would be to go beyond the terms of reference, which simply concern themselves with identifying heritage resources and offering advice on mitigation. The families of concerned individuals are only likely to be contacted (and informed, not consulted) once the relevant governmental authority approves the development and exhumations have been suggested (if the graves cannot be avoided and protected in situ). Any suggestion or pressure from contract archaeologists at this point that graves may need to be destroyed during development (rather than to be relocated with appropriate respect) would, of course, create an immediate ethical issue. This raises an important question: whose interests are contract archaeologists serving?

\section{Who are contract archaeologists serving?}

While legislation has created an environment under which contract archaeology has flourished, it has not provided clarity for contract archaeology. For example, Section 36 of the NHRA makes a reference to concerted effort:

'SAHRA or a provincial heritage resources authority may not issue a permit for any activity under subsection (3) (b) unless it is satisfied that the applicant has, in accordance with regulations made by the responsible heritage resources authority -

(a) made a concerted effort to contact and consult communities and individuals who by tradition have an interest in such grave or burial ground; and 
(b) reached agreements with such communities and individuals regarding the future of such grave or burial ground' (NHRA 1999: 62).

What 'concerted effort' is and how early in the application phase should a contract archaeologist have to engage in community archaeology are not well defined. How participatory is the engagement that is undertaken much later in the application process when the options for Indigenous African communities are extremely limited? Thus, the current approach to community engagement in terms of significant archaeological sites does not necessarily promote a contract archaeology that has an active engagement with indigenous communities from its earliest stages (Funari 2001). A number of other issues also need considering. For example, where people were forcefully removed from their land under apartheid the generalised perception of what concerted effort means leaves much to be desired. Can an advertisement by a contract archaeologist in the local newspaper and a notice on site be deemed to be adequate social consultation? What about the consideration of the area's local history? What if the family members were relocated? Should the contract archaeologist be mandated to also ensure that advertisements are placed in areas to which people were forcibly relocated?

Most archaeologists around the world now promote a participatory approach. Such an approach involves working with the communities affected by their work in various ways, depending on the nature of the work being undertaken (e.g. Moser et al. 2002; Phillips 2008; Chirikure et al. 2010). According to Moser et al. (2002), community members are meant to have some control at every stage of the project. While they were writing using Egyptian case studies, the views expressed in their publication are generally accepted as defining community archaeology on the international scene (Moser et al. 2002; Atalay 2006; Chirikure et al. 2010). In the case of the relocation of graves in South Africa as I discussed above, what form of control can community members be assigned when they have no legal authority to refuse grave relocations at such a late process in the EIA process? While it is easier said than done that communities must have some control of our archaeological activities, to what extent do contract archaeologists make an effort to ensure that they not only serve the interests of the paying client against those who have a constitutional right to offer their views?

At the core of community archaeology is an interest by those involved to accept the political nature of the discipline of archaeology and to help decolonise it (Spector 1993; Pyburn 2004, 2008; Atalay 2006). I would argue that contract archaeologists have not done enough to challenge legal frameworks that still fail to provide an effective consideration of the cultural interests of Indigenous African communities, nor to decolonise the discipline of archaeology as a whole.

It is clear, therefore, that the interests of the paying client are given greater weight over those of Indigenous African communities even when the discipline of archaeology is attempting to transform itself from the colonial attachments. Such actions are, in my view, failing the discipline of archaeology and are also closely linked to the failure by contract archaeologists to communicate their findings within the discipline or to the public at large.

\section{Accessibility of the 'grey literature'}

Kinahan (2013: 1) defends contract archaeologists from the usual criticism of not publishing their findings in the following terms: 'to produce publishable research results, and thereby hold up his or her head as an archaeologist, the contractor must first do the work, wait to be paid, and then, if motivated to develop the project further, find some way 
of funding it.' If one considers the fact that contract archaeologists are more active than most 'research archaeologists', it is clear that they are thus exposed to identifying more archaeological sites than their counterparts in academia. Further consideration of this fact will reveal that contract archaeologists are more able to identify patterns in the particular area(s) surveyed while also being the ones with the opportunity to salvage sites that would otherwise have been destroyed. While I agree with the arguments put forward by Kinahan (2013) that contract archaeologists do not necessarily have the same benefits as the 'academic archaeologists' in terms of research funds and accruing benefits from publications, what is the ethical responsibility of these professionals within the discipline for ensuring that such significant sites are known about?

In South Africa, creation of the South African Heritage Resources Information System (SAHRIS) is now making a number of these grey reports available. SAHRIS is a heritage management tool introduced by SAHRA to facilitate contact with interested and affected parties. This can cover their comments on applications with heritage significance or their interaction with SAHRA and other heritage authorities on other matters of significance as governed by existing heritage legislation. But if one considers the quality of such reports and the level of unnecessary repetition in them, is this the best way for contract archaeologists to communicate their findings? Kinahan (2013: 1) argues that 'The report is in a format dictated by the client and is, moreover, the property of the client'. This element was also one of the main arguments discussed at the last ASAPA workshop on contract archaeology held at the University of Cape Town in January 2012, as well as at a much earlier one held in 2006 at the University of South Africa in Pretoria.

While documents submitted to government agencies and departments as part of the approval process for a proposed development are supposed to be public, strong objections were expressed by some of those attending these meetings to their reports being considered public documents, notwithstanding the legal requirements to freedom of information provided by the Promotion of Administrative Justice Act (No. 3 of 2000) and the Promotion of Access to Information Act (No. 2 of 2000). Far from being in the hands of the contract archaeologist, publication or dissemination of the contents of such a report should be dictated by the requirements of the relevant heritage authority as stated by the 1999 National Heritage Resources Act. But if the quality of these reports is such that it is even difficult to detect the significance of archaeological sites identified, what value do they add to the discipline of archaeology in general?

I submit that besides the argument made by Kinahan (2013) that contract archaeology reports are meant for a different audience, another issue needs to be considered, namely their quality, in order to make certain that no archaeologists are working beyond their accreditation levels, i.e. covering areas for which they have no relevant experience, sometimes even without being members of ASAPA, given that this is not a registered professional body and that no legislative framework exists that requires accreditation by ASAPA. This is an important issue and its resolution requires that ASAPA's members should encourage accredited professionals to abide by its code of conduct so that action can, where necessary, be taken against those who operate outside their area of expertise. The failure to enforce this code of conduct is one of the leading reasons for sub-standard reporting of contract archaeology in South Africa at the present time. Becoming a registered professional body that can administer the affairs of all practising archaeologists in South Africa is not by itself a solution, but would mean that ASAPA would then have the necessary legal mandate to manage the activities of all archaeologists in the country instead of only considering breaches of its ethical code by its own members, as is the case at present. 
ASAPA's current accreditation system depends upon the experience and academic qualifications of the member concerned. There are three categories: field supervisor, field director and principal investigator. The implementation of these accreditation categories has encountered many challenges. For example, contract archaeologists with field supervisor and field director accreditation cannot work without a principal investigator, but nevertheless often do, directly contravening ASAPA's own rules. In the absence of a grievance raised by one member against another, the ASAPA Council has historically not acted against contract archaeologists who work beyond their accreditation levels. I am of the view that this is passing the responsibility to membership and a refusal by an accounting authority to act in accordance with the powers it has been given. How long, one might ask, will successive ASAPA Councils fail to act against members who are intentionally not abiding by the code of ethics of the organisation?

Besides ASAPA, Amafa aKwaZulu-Natali, the Provincial Heritage Agency in the province of KwaZulu-Natal, also has an accreditation system for archaeologists working there and currently almost 30 archaeologists are accredited in this system. While accreditation as a contract archaeologist is not mandatory, those who are accredited with both ASAPA and Amafa aKwaZulu-Natali stand a better chance of getting business. Thus, contract archaeologists see accreditation as a means of marketing themselves to stand a better chance of obtaining a contract. Some developers or environmental consultants approach heritage authorities for the list of contract archaeologists they deem qualified enough and in good standing with them in terms of the quality of their work. Heritage authorities in South Africa mainly use the ASAPA list of accredited specialists. It is thus of great concern that the ASAPA Council does not take disciplinary action against professionals who fail to adhere to the code of ethics relating to how contract archaeology is conducted. Besides waiting for individual members to submit a grievance against another member considered to be flaunting the code of ethics, Council expects heritage resource authorities to be address the poor work of ASAPA members. From discussions I have held with various staff members at SAHRA, it is clear that they have begun to lead the way in rejecting reports of poor quality and in some cases SAHRA has approached ASAPA to act on perennial offenders, although we are yet to see public evidence of action being taken that might serve as an example of what can happen when members continuously fail to abide by the Association's agreed code of conduct.

To highlight just how rife the problem of poor reporting is, I now consider a number of various challenges experienced by heritage officials, namely missing information, identifying the significance of a site(s), poor recommendations, the use of templates and the length of reports. These challenges are informed by my experience of working for heritage authorities in South Africa and by discussions I have held with heritage officials around the country. It should be noted that these challenges are generally similar around the country and are thus not limited to certain provinces.

\section{Missing information}

Some reports lack the most basic details to go with them, including the methodology used, or the provision of site maps, images, GPS tracks and site recording sheets to support the information provided in the reports. Providing a detailed methodology helps heritage officials to assess the recommendations provided. Having no maps simply means that any recommendations made cannot be directly linked to the nature of the impact that will happen as the result of the proposed development activity. The comment/excuse often given when heritage authority officials request such maps is that the client did not 
provide them, but if understanding of what a project involves is so poor, should we be confident that the assessment undertaken was with the appreciation of the nature of impact that is likely to happen on-site? To make up for this limitation, SAHRA officials often have to read the Environmental Impact Assessments (EIAs) to get an adequate understanding of the project. Provision of information relating to GPS tracks is also vital as this serves the twin purposes of helping heritage authorities to identify whether the contract archaeologist did indeed go on-site and of indicating all the areas that were surveyed so that they can have confidence that the recommendations made in the report are informed by a detailed assessment.

\section{Identifying the significance of a site(s)}

Often, not enough information is provided to support the significance attributed to the particular sites identified. A presentation by Ms Radford van de Venter at the ASAPA Conference held in Gaborone, Botswana, in July 2013 highlights these problems in detail. During her presentation, she highlighted concerns by the South African Police Service and the Public Protector that 'expert' reports did not provide a very detailed basis for the recommendations provided. Instead, some reports have statements that are not referenced, justified or explained. This challenges the 'expert' opinions supposedly reflected in them. In an example she discussed, a HIA was undertaken following damage to an archaeological site that had previously been demarcated. The author said that this was 'probably' an Iron Age site, though without providing any evidence to support this. Such lack of clear and detailed description of an identified site and the rating of its significance is of concern to legal practitioners. It is the recommendation of both the South African Police Service and the Public Protector that practitioners should provide supporting evidence for the statements they make in their assessment reports by making reference to previous research undertaken in the relevant area. SAHRA, too, has minimum standards in place for the completion of impact assessments, and had these been followed, some of these inadequacies would not be experienced. Failure to adhere to these standards might simply be about ignorance with regard to why they are significant and why heritage authorities require that certain information be provided in all assessment reports, but the experience of Amafa aKwaZulu-Natali suggests that some contract archaeologists have a tendency to accord certain categories of heritage a particular level of significance determined by their own field of expertise! If so, there can plainly be little or no consistency in how significance is assigned to archaeological sites.

\section{Poor recommendations}

In the world of competitive tendering, some reports have 'sitting on the fence' recommendations. Some of these may not be expressed in a clear and unambiguous manner as would be expected under normal circumstances. By this, I mean that some contract archaeologists do not seem to have the confidence to commit themselves to the recommendations and mitigation procedures they provide in the assessment reports. As a direct result, the recommendation often given in the executive summary and the conclusion of the given reports are open-ended, leaving the greater responsibility to the deciding authority. It should be a matter of considerable concern if a contract archaeologist, who has been on-site, cannot identify a site, assess its significance, identify the nature of impact as a result of development or be able to make definite and precise recommendations. I view this as possibly an indirect and probably unconscious 
marketing tool in that the particular contract archaeologist always secures a positive decision on behalf of the developer. Such 'safe' recommendations lack decisiveness and put the responsibility on the relevant heritage authority that must then make a decision based on poorly defined, safe and 'on the fence' recommendations. It is even more problematic when the information provided in the assessment reports does not directly link to the recommendations given, no matter how weak they may be. Reports of this nature tend to argue that a located site is of high significance, even though the recommendations and content of the report do not clearly reflect this. Recommendations are also directly linked to the affordability level of a given client. Where contract archaeologists are of the opinion that the client can afford expensive mitigation measures, this is often reflected in the assessment reports they submit.

\section{The use of templates}

Directly linked to the challenge of poor recommendations is the over-use of report templates. There are many cases where contract archaeologists merely change the title and description of the assessment report, creating a level of repetition that makes it difficult to objectively and critically assess the report submitted. The experience of SAHRA staff members is that such over-reliance on report templates encourages limited description of identified heritage resources and the provision of standard comments on them completely fails to note that there are differences between one site and the next. For some contract archaeologists, relying too much on report templates may derive from their confidence in their knowledge of an area in which they are well experienced, but even if this is so there may well be sites present that, by reason of their age or other characteristics, fall outside the specific expertise of an individual researcher. Experience has frequently shown that major archaeological sites, which could have been reasonably identified at the survey stage, may be 'discovered' during the developmental stage, leading to very costly delays for the developer. Therefore, if, for example, a contract archaeologist with no experience of dealing with shell-middens is working in a coastal area, he or she should take the responsibility of working with an appropriately qualified and experienced specialist in that area of archaeology.

\section{Length of reports}

The length of reports is also a challenge that needs to be highlighted. While heritage authorities may never know how much certain contract archaeologists have been paid for a given report, there is enough evidence, some of it gathered through private discussions, that some may provide more detailed, lengthy and well-illustrated reports for projects where they have been better paid. If so, then the quality of reports is clearly not entirely reflective of the experience possessed by a given contract archaeologist. Worse, in some cases individual contract archaeologists may allow environmental companies to use their names for reports that they have not directly produced, lending credibility to those reports in terms of their authorship, if not their the content. By way of example, when Amafa aKwaZulu-Natali raised concerns over one particular assessment report for the Vryheid area in 2012 (because officials noted that the style in which it was written was not consistent with that of the person named on its cover), the 'author' admitted that he had not actively participated in writing the HIA!

The fact that the deficiency was picked up illustrates the significance of knowing the archaeological area within which a compliance officer has to operate. In addition to the 
HIA above, an Amafa aKwaZulu-Natal employee was able to identify a number of historical aspects that had been overlooked in another HIA submitted for review. In this HIA, the contract archaeologist (who is actually a historian by background) mentioned that there were no heritage sites found in the area he had surveyed in the former Zululand. In fact, there is a significant body of literature that refers to the heritage sites of this region, some of which still hold significance for local communities. Thus, by employing experienced compliance officers, heritage authorities can ensure that such shoddy reports are identified and acted upon appropriately. Such experienced officers also get to know the different practitioners and the area within their jurisdiction very well, which allows them to play a critical oversight role in reviewing assessment reports.

While heritage authorities have a role as well in ensuring that Indigenous African communities are better involved in the social consultation phase of environmental impact assessment and that contract archaeologists work within their areas of expertise, ASAPA and its Council have an even bigger role to play. The professional body cannot distance itself from taking stringent measures against its own members. I am of the view that ASAPA needs to institute a period of transition, whereby it sets a deadline for taking action against those contract archaeologists not abiding by its code of ethics, continuously undertaking unsatisfactory work or accepting work in areas in which they have no experience because it is beyond their accreditation levels. ASAPA membership should not simply be about increasing one's profile to stand a better chance of securing contract work.

Considering these many difficulties, I ask a further important question: to what extent have contract archaeologists played a positive role in the meaningful transformation of South African archaeology?

\section{Transformation and contract archaeology}

I have previously argued that South African archaeology is predominately white and that this is the result of the political paradigm that was prevalent in the country for many years (Ndlovu 2009; Smith 2009). To achieve a more equitable racial balance within the discipline ASAPA adopted a Transformation Charter in 2008, in support of which I noted that 'it is therefore imperative that all archaeologists in the country join hands and find a solution to the challenges faced by archaeology. There is an urgent need to move away from verbal promises and to act decisively. It is high time that we see the implementation of an inclusive transformation plan, which must be formulated with the input of all relevant stakeholders, particularly those people affected by the lack of transformation' (Ndlovu 2009: 91). Because many more archaeologists are finding employment in the area of contract archaeology than anywhere else in the discipline, contract archaeologists have a particular responsibility for the successful attainment of a truly transformed South African archaeological community. However, their role is yet to be satisfactory in this regard.

While some contract archaeologists have enabled African graduates of archaeology to get employment and training on the job, this practice has not been sufficiently widespread. For example, during a workshop I attended in January 2012 at the University of Cape Town, there seemed to be opposition to the idea of contract archaeologists providing African graduates with training opportunities in their companies. Company directors also complained that they would have to 'babysit' such aspiring archaeologists and that this would potentially increases the overhead expenses for their organisations. In addition, the argument put forward was that a number of companies involved in contract 
archaeology are too small and thus do not have a sufficiently high turnover for such provision to be possible. However, for those contract archaeology companies with a turnover of over R 500,000 per year, it is possible to claim half of the $1 \%$ contribution they pay to the relevant Sector Education and Training Authority (SETA) as part of the Department of Labour's Skills Development Levies. Is it not therefore possible that such government regulations could be used to the advantage of the archaeological discipline in order to ensure that meaningful transformation efforts are put in place? As discussion proceeds on how best to achieve this goal (see Hubbard 2013) much more attention needs to be given to these issues and to that of meaningful transformation as a whole, not least because of the seeming lack of interest in these topics on the part of many influential figures within the discipline when they were debated at last year's ASAPA conference in Gaborone, Botswana.

\section{Conclusion}

There is little dispute over the significant role that contract archaeology has played in the development of South African archaeology. A number of archaeological sites are today known only because they were brought to the attention of the archaeological community by contract archaeologists. I offer three examples here. The first is Liphofung in the northwest of Lesotho. Now developed as a site museum and nature reserve, this is one of three sites excavated in the 1990s ahead of the implementation of Phase IA of the Lesotho Highlands Water Project, a major dam-building and water supply project in Lesotho. Considering that it is among less than 20 sites excavated in Lesotho as a whole, analysis of the finds from it is of crucial significance for understanding that country's prehistory (Kaplan and Mitchell 2012). My second example comes from a Phase 2 Archaeological Impact Assessment conducted by Tom Huffman of the Department of Archaeology, University of the Witwatersrand, near Thabazimbi in Limpopo Province, South Africa, where maize grindstones associated with burnt house floors were excavated. This mitigation-enforced excavation contributed substantially to discussions of when maize was introduced into the area compared to the situation in KwaZulu-Natal (Huffman 2012). Finally, one of the most significant first millennium Farming Community archaeological sites in KwaZulu-Natal itself — Ndondonwane - was first discovered in 1992 following CRM work undertaken as a result of a proposed regional water scheme (van Schalkwyk et al. 1997). While Hilary Deacon (1988) was correct in his prophecy that contract archaeology is the future of archaeology, its operation raises a number of concerns, some of which are addressed in this paper. The aim here has not been to dismiss the role of contract archaeology in the growth of the discipline, but simply to highlight some of the issues that need to be addressed.

First and foremost, contract archaeologists need to engage much more effectively in community consultation, as I discussed above with regard to the question of grave relocations. Furthermore, they must ensure that they engage in meaningful discussions over how best to take the 'grey literature' that they produce to a level at which it can be shared by a greater number of people. The concern raised by some that they do not have the 'luxury' granted to academic researchers and their associates at universities, who receive financial incentives for their publications from the state can, perhaps, be met by approaching academic institutions with a view of being appointed as research associates. Most significantly, however, contract archaeologists should also play a more prominent role in the overall transformation of South African archaeology. Only then can we begin 
to discuss ethical standards, because only then will South African archaeology be a truly representative academic discipline.

\section{Notes on contributor}

Ndukuyakhe Ndlovu obtained his PhD from Newcastle University in the United Kingdom. He is currently a Senior Lecturer in Archaeology in the Department of Anthropology and Archaeology, University of Pretoria. He has over ten years' experience in heritage management in South Africa, having worked for both national and provincial heritage authorities in various capacities and presently serving on the Boards of two heritage authorities. His research interests include southern African rock art, the transformation of South African archaeology and the management of Africa's rich cultural heritage.

\section{References}

Atalay, S. 2006. "Indigenous archaeology as decolonizing practice." The American Indian Quarterly 30: 280-310. doi:10.1353/aiq.2006.0015.

Carter, S. 2002. "Contract archaeology in Scotland." Antiquity 76: 869-873.

Chirikure, S., Manyanga, M., Ndoro, W., and Pwiti, G. 2010. "Unfulfilled promises: community participation at some of Africa's World Heritage Sites." International Journal of Heritage Studies 16: 30-44. doi:10.1080/13527250903441739.

Deacon, H.J. 1988. "Guest editorial: what future has archaeology in South Africa?" South African Archaeological Bulletin 43: 3-4.

Deacon, J. 1993. "The Cinderella metaphor: the maturing of archaeology as a profession in South Africa." South African Archaeological Bulletin 48: 77-81. doi:10.2307/3888945.

Funari, P.P.A. 2001. "Public archaeology from a Latin American perspective." Public Archaeology 1: 239-243. doi:10.1179/pua.2001.1.4.239.

Green, W. and Doershuk, J.F. 1998. "Cultural resource management and American archaeology." Journal of Archaeological Research 6: 121-167.

Halkett, D. 2010a. "Heritage Scoping Assessment of a proposed Wind Energy Facility to be situated on farms in the Cookhouse District, Eastern Cape." Unpublished report submitted to Savannah Environmental (Pty) Ltd.

Halkett, D. 2010b. "Heritage Impact Assessment of the proposed Amakhala-Emoyeni Wind Energy Facility, Cookhouse District, Eastern Cape." Unpublished report submitted to Savannah Environmental (Pty) Ltd.

Hall, M. 1989. "Guest editorial. Contract archaeology in South Africa." South African Archaeological Bulletin 44: 63-64. doi:10.2307/3888324.

Hall, M. 1989. "The archaeology of colonial settlement in southern Africa." Annual Review of Anthropology 22: 177-200. doi:10.1146/annurev.an.22.100193.001141.

Hubbard, P. 2013. "ASAPA Conference 2013: a view from Zimbabwe." Digging Stick 30(3): $23-24$.

Huffman, T. 2012. "Maize grindstones, Madikwe pottery and ochre mining in precolonial South Africa." Southern African Humanities 18(2): 51-70.

Kaplan, J. and Mitchell, P.J. 2012. "The archaeology of the Lesotho Highlands Water Project Phases IA and IB." Southern African Humanities 24: 1-32.

Kinahan, J. 2013. "Guest editorial. Africa heat and dust: some reflections on contract archaeology in southern Africa." South African Archaeological Bulletin 68: 1-2. doi:10.1016/j. sajb.2013.01.003.

Kleinitz, C. 2013. "Between valorisation and devaluation: making and unmaking (world) heritage in Sudan." Archaeologies: Journal of the World Archaeological Congress 9: 427-468.

McGimsey, C.R. 1972. Public Archaeology. New York: Seminar Press.

Moser, S., Glazier, D., Phillips, J.E., Nemr, L.N.E., Mousa, M.S., Aiesh, R.N., Richardson, S., Conner, A. and Seymour, M. 2002. "Transforming archaeology through practice: strategies for collaborative archaeology and the Community Archaeology Project at Quseir, Egypt." World Archaeology 34: 220-248. doi:10.1080/0043824022000007071.

Ndlovu, N. 2009. "Transformation challenges in South African archaeology." South African Archaeological Bulletin 64: 91-93. 
Ndlovu, N. 2011. "Legislation as an instrument in heritage management - is it effective?" Conservation and Management of Archaeological Sites 13: 31-57. doi:10.1179/175355211X 13097877338932.

Ndlovu, N. 2012. "Archaeology and development at loggerheads: but should they be?" South African Archaeological Bulletin 67: 262-272.

Phillips, C. 2008. "Comment on community involvement in archaeology and cultural heritage management: an assessment from case studies in southern Africa and elsewhere." Current Anthropology 49: 479-480.

Pyburn, A.K. 2004. "Rethinking complex society." In Ungendering Civilization, edited by A.K. Pyburn, 1-46. New York: Routledge.

Pyburn, A.K. 2008. "Public archaeology, Indiana Jones, and honesty." Archaeologies:Journal of the World Archaeological Congress 4: 201-204.

Rudner, J. 1982. "The legal protection of prehistoric and historic relics in South Africa." South African Archaeological Bulletin 37: 5-6. doi:10.2307/3888575.

Scheermeyer, C. 2005. "A changing and challenging landscape: heritage resources management in South Africa." South African Archaeological Bulletin 60: 121-123.

Smith, B.W. 2009. "A Transformation Charter for South African archaeology." South African Archaeological Bulletin 64: 87-89.

Spector, J.D. 1993. What This Awl Means: Feminist Archaeology at a Wahpeton Dakota Village. St Paul. Minnesota Historical Society.

van Schalkwyk, L., Greenfield, H. and Jongsma, T. 1997. "The early Iron Age site of Ndondondwane, Kwazulu-Natal, South Africa: preliminary report on the 1995 excavations." Southern African Field Archaeology 6: 61-77.

van Schalkwyk, L. 2006. "Heritage impact assessment of Nsami Dam, Giyani, Limpopo Province, South Africa." Unpublished report submitted to Cave Klapwijk and Associates.

Van Waarden, C. n.d. "Archaeology and development in Botswana." http://www.african-archaeology. net/Nsi/nsi2_9-11.pdf Site accessed 28 July 2009. 